\title{
Relationship Between the Role of Educators and Old People against Youth Attitudes on Prevention of Premarital Sex in Balikpapan
}

\author{
Hazanah, Sri*, Hendriani, Dwi, Firdaus, and Rivan \\ Poltekkes Kemenkes Kalimantan Timur, Jl. W. Monginsidi No. 38, Sidodadi, Samarinda Ulu, Kota Samarinda, \\ Kalimantan Timur 75243, Indonesia \\ *Corresponding author: srihazanah@gmail.com \\ Type of the Paper (Article)
}

Received: May 21, 2019; Accepted: August 06, 2019; Published: August 12, 2019 https://doi.org/10.29253/achnr.2019.15022

\begin{abstract}
Adolescence is a period of transition between childhood and adulthood, experiencing changes in mental, emotional, social, physical, and sexual maturity. If there is no supervision, direction, guidance from the closest person such as parents, family, educators, there might be unexpected sexual deviations such as pregnancy and premarital sex. The aim of the study was to find out the relationship between the role of educators and parents on the attitudes of adolescents in preventing premarital sex in Balikpapan in 2017. The survey research method was a cross-sectional design. Study sample 119 students of Balikpapan Health Vocational School aged 14-18 years, taking techniques using Random Sampling. Data research techniques using questionnaires with a Likert scale. Data analysis used univariate analysis with frequency distribution, bivariate analysis with chi-square $\left(\mathrm{x}^{2}\right)$ statistical test and multivariate logistic regression test with significance $\mathrm{p}<0.05$. The results of the study: the role of educators supports $68(57.1 \%)$, the role of parents supports $72(60.5 \%)$, and positive teen attitudes 62 $(52.1 \%)$ there is a relationship between the role of educators in adolescent attitudes with a value $(\mathrm{OR}=$ $2.504,95 \%$ CI $(1.19-5.27)$ p-value $=0.024)$, there is no relationship between the role of parents on adolescent attitudes with values $(\mathrm{OR}=2.185,95 \% \mathrm{CI}(1.03-4.62)$ and $\mathrm{p}$-value $=0.061$ Strength regression test the relationship between the role of parents $\mathrm{OR}=(0.74)$ and the role of educators $\mathrm{OR}=$ (0.57). the role of people old there is no relationship but the more dominant influence on changes in adolescent attitudes compared to the role of educators, it needs to be a concern of all parties because adolescents are a time to seek self-identity so that the environment is easily influenced. Suggestion: parents, educators and other parties (religion, government) pay more attention to adolescents to avoid premarital sex deviations.
\end{abstract}

Keywords: the role of educators; parents; adolescent attitudes

\section{Introduction}

Adolescence is a transitional period beginning with puberty, namely the occurrence of physical changes and physiological functions. Changes in the body will also be accompanied by the gradual development of the characteristics of priors and secondary characteristics (Kusmiran, 2011). The development includes mental, emotional, social and physical maturity. P Indonesia Economic adolescents 
are physically reproductive health issues into moral and social health problems, possible deviations are not expected to appear like; sexual behaviour (Sarwono, 2012).

Some research shows, young men and women have had sex. There are 2.3 million abortion cases in Indonesia and 20\% done by teenagers (BKKBN, 2009). Adolescent free sex is caused by low parental supervision, changes in norm values about sex tend to start loosening, peer pressure, minimal sex education, implementation of low religious values both by the adolescent itself and the environment around, watching porn videos, teen associations that are increasingly free and economic status family (Yanti, et al, 2016).

The results of the study in Samarinda City by Purwanto and Kalsum (2016), of the 125 respondents studied, most of the respondents are manifold female sex is as much as 72 people (57.6\%), most respondents were taking education at the high school/vocational school level namely as many as 87 people (69.6\%), and most of the respondents are 19 years old year as many as 25 people $(20.0 \%)$. Respondents who did sexual activity "Hand in hand Hands " by 97.6\% , "Cuddling and Caressing " at $59.2 \%$," Kissing " at $68.0 \%$, "Kissing with Tongue" by 56.0\% , "Feeling - touching genitals" by $45.6 \%$, "Masturbation or Masturbation" by $35.2 \%$, "Oral Sex" by 44.0\%, "Sex Through Anus" of $34.4 \%$, and "Vaginal Sex" is $45.6 \%$.

Research by Siswandwika (2017), that there is a statistically significant relationship between roles parents according to student perceptions of adolescent attitudes against free sex with a value of $p=0.004$ $<0.05$.

\section{Methods}

This research method is quantitative by using analytic survey research design and cross-sectional approach, namely: where the independent variables and dependent variables are taken at one time / do not see the relationship between variables based on time travel (Nursalam, 2008). The study population was all students of Balikpapan Health Vocational School aged 14-18 years. Stratified random sampling technique (Random Sampling) amounted to 119 respondents.

The independent variable or exposure factor of this study is the role of educators and parents, the dependent variable of the results assessed is adolescent attitudes in preventing premarital sex. The study population was all students of Balikpapan Health Vocational School aged 14-18 years. Stratified random sampling technique (Random Sampling) amounted to 119 respondents.

The data collection tool uses a questionnaire by providing a set of questions or written statements that are made based on indicators of a variable (Dharma, 2011). The analysis of this study is univariate analysis and bivariate analysis with a square $x^{2}$ chi test. Furthermore, the study continued with multivariate analysis, to see or strengthen the independent variables with categorical dichotomous variables using Linear Regression Test analysis with significance level p-value $<0.05$.

\section{Results}

Table 1. Distribution of Frequency of Characteristics of Respondents Based on Age and Gender.

\begin{tabular}{ccc}
\hline Characteristics of Respondents & Frequency & Percentage (\%) \\
\hline 1. Age & & \\
a. 14 years & 21 & 17.6 \\
b. 15 years & 61 & 51.3 \\
c. 16 years & 31 & 26.1 \\
d. 17 years & 4 & 3.4 \\
e. 18 years & 2 & 1.7 \\
2. Gender & 10 & \\
a. Man & 109 & 8.4 \\
b. Women & $\mathrm{N}=119$ & 91.6 \\
Total & \\
\hline
\end{tabular}

Based on the table above, it can be seen that the majority of the age at the age of 15 is 61 respondents (51.3\%), the age of at least 18 years 2 respondents (1.7\%). Gender is mostly female with 109 respondents $(91.6 \%)$ and at least male 10 respondents $(8.4 \%)$. 
Table 2. Variable frequency distribution of the role of educators and parents towards adolescent attitudes in preventing premarital sex.

\begin{tabular}{lcc}
\hline Research variable & Frequency & Percentage (\%) \\
\hline 1. The Role of Educators & & \\
a. Support & 68 & 57.1 \\
b. Does not support & 51 & 42.9 \\
2. The role of parents & & \\
$\quad \begin{array}{l}\text { a. Support } \\
\text { b. Does not support }\end{array}$ & 42 & 60.5 \\
3. The Role of Educators & 62 & 39.5 \\
$\quad$ a. Positive & 57 & 52.1 \\
b. Negative & $\mathrm{N}=119$ & 47.9 \\
Total
\end{tabular}

Based on the above table it can be seen that the role of the majority of educators supports, as many as 68 respondents $(57.1 \%)$ and none as many as 51 respondents $(42.9 \%)$. The role of parents most supports 72 respondents $(60.5 \%)$ and none of the 47 respondents $(39.5 \%)$. While positive teen attitudes were 62 respondents (52.1\%) and negative ones 57 respondents $(47.9 \%)$.

Table 3. Results Analysis of the relationship between the role of educators and parents on adolescent attitudes in preventing premarital sex.

\begin{tabular}{|c|c|c|c|c|c|c|c|c|}
\hline \multirow{2}{*}{ VARIABLES } & \multicolumn{4}{|c|}{ Youth attitude } & \multicolumn{2}{|c|}{ Total } & \multirow{2}{*}{$\begin{array}{c}\mathrm{P} \\
\text { Value }\end{array}$} & \multirow{2}{*}{ OR } \\
\hline & Positive & $\%$ & Negative & $\%$ & $\mathbf{N}$ & $\%$ & & \\
\hline \multicolumn{9}{|l|}{ The role of educators } \\
\hline a. Support & 42 & 61.8 & 26 & 38.2 & 68 & 100 & 0.024 & 2.504 \\
\hline b. Does not support & 20 & 39.2 & 31 & 60.8 & 51 & 100 & & \\
\hline \multicolumn{9}{|l|}{ The role of people old } \\
\hline a. Support & 43 & 59.7 & 29 & 40.3 & 72 & 100 & 0.061 & 2.185 \\
\hline b. Does not support & 19 & 24.5 & 28 & 59.6 & 47 & 100 & & \\
\hline
\end{tabular}

Based on the Table shows that of the 68 respondents whose role of educator supports and has a positive attitude as many as 42 respondents (61.8\%) and negative attitudes 26 respondents $(38.2 \%)$, while of 51 respondents the role of educators who do not support have a positive attitude as much as 20 respondents (39.2\%) and negative attitude 31 respondents (60.8\%). After doing statistical tests using the Chi-Square test with a $95 \%$ confidence level obtained $p$-value 0.024 which means less than $p<0.05$, thus, there is a relationship between the role of educators and attitudes of adolescents aged 14-18 years in the prevention of sexual sex.

The role of parents shows that from 72 respondents whose parents' role supports and has a positive attitude as many as 43 respondents (59.7\%) and negative attitudes 29 respondents (40.3\%), while from 47 respondents the role of parents who do not support have an attitude positive as many as 19 respondents $(24.5 \%)$ and negative attitude 28 respondents (59.6\%). After doing statistical tests using the Chi-Square test with a 95\% confidence level obtained p-value 0.061 which means less than $p>0.05$, thus, there is no relationship between the role of parents and adolescent attitudes.

Model 1 was made to see the relationship between the independent variables of the role of educators and parents with the dependent variable of adolescent attitudes. The results of the statistical test analysis showed that there was no interaction between the role of educators on adolescent attitudes in which the $p$-value $=0.212$ means greater than $p>0.05$ and the results of the analysis data obtained OR $=(-0.559-919) / 919=0.9 \%, 95 \% \mathrm{CI}=0.24-1.37$. The relationship between the role of parents towards positive and negative adolescent attitudes shows that there is no interaction where $\mathrm{p}$ value $>0.05$ with $\mathrm{p}$ value $=0.495$ and the results of data analysis obtained $\mathrm{OR}=(0.296-919) / 919=0.9 \%, 95 \% \mathrm{CI}=0.32$ 1.74. Interpretation: after confounding analysis, the role of educators and parents who support have the 
same opportunities for positive attitudes of adolescents, namely 9 times in prevention of premarital sex, but the role of parents has a greater influence than the role of educators with $\mathrm{OR}=0.74 \%$ and $0.57 \%$. Thus the variable role of educators and parents is an opportunity risk factor for the occurrence of premarital sex in adolescents.

Table 4. Relationship Logical regression analysis of the role of educators and parents on adolescent attitudes in preventing premarital sex.

\begin{tabular}{lcccc}
\hline \multicolumn{1}{c}{ VARIABLES } & \multicolumn{2}{c}{ MODEL } & \multirow{2}{*}{ Exp (B) } & P Value \\
\cline { 2 - 3 } & OR & $\mathbf{9 5 \%}$ CL & & \\
\hline The role of educators & & & $0.559 \%$ & 0.212 \\
$\begin{array}{l}\text { a. Support } \\
\text { b. Does not support }\end{array}$ & $20.57 \%$ & $(0.24-1.37)$ & \\
The role of parents & & & $0.296 \%$ & 0.495 \\
$\begin{array}{l}\text { a. Support } \\
\text { b. Does not support }\end{array}$ & $0.74 \%$ & $(0.32-1.74)$ & & \\
\hline
\end{tabular}

\section{Discussion}

\section{a. Adolescent Attitude}

The results of the study of adolescent attitudes in the prevention of premarital sex were the most positive 62 respondents (52.1\%) and the least negative were 57 respondents (47.9\%). This means that the attitude of adolescents responds positively to both directness and say very agree and usually, people judge or see something as deemed important, is aware of the role of educators and parents overseeing, assisting, reminding them in preventing premarital sex. Attitude is the opinion and belief of a person towards an object or situation that is accompanied by certain feelings so as to provide a basis for the individual to respond or behave in the way he chooses (Azwar, 2012). The results of this study indicate that half of the respondents are positive about preventing premarital sex, which means that respondents place sex in accordance with their functions and goals, do not consider sex disgusting, taboo and obscene, follow rules in a scientific context or learn to understand themselves and others. In addition, some respondents have received sex education material/information and have received information on the prohibition of violating moral ethics and sanctions for terminating/terminating schools. Putri's research (2011), states that the better the adolescent's knowledge about premarital sex, the premarital sexual behaviour of adolescents is getting better ( $p$-value $=0,000)$.

The results of the study also obtained respondents who were negative towards the prevention of premarital sex, this might be due to the impact of technological advances that make it easier for teens to access pornographic sites on the internet. Darmasih's research (2009) stated that fewer sources of information obtained by adolescents about sex, the better sexual behaviour of teenagers and vice versa ( $p$-value $=0.022$ ). Concerned research (2007), states that there is a significant relationship between the role of mass media and adolescent attitudes toward premarital sex ( $p$-value $=0.009$ ). According to Kartono (2013), the factors that influence the formation and alteration of individual sexual attitudes include internal and external factors. Internal factors are obtained from individuals, where individuals receive, process and choose everything that comes from outside, while external factors from outside the individual, in the form of stimulus to form and change attitudes. The stimulus can be either direct, for example, individuals with individuals, or individuals with groups, can also be indirect namely through intermediaries, such as communication aids and mass media.

\section{b. The Role of Educators}

The results of the study of the role of educators in preventing premarital sex were the most supported by 68 respondents (57.1\%) and no 51 respondents (42.9\%). This means that respondents get good care, openness between education and adolescents and get the right and correct information to 
prevent premarital sex. On the other hand, there is no possibility of support because educators do not want the educator's environment to be polluted with this disgrace because they are already considered adults so that whatever is done has already been considered beforehand. According to Yusuf (2013), an optimal effort to prevent and prevent sexual behaviour in adolescents is the role of educators who have a major influence on the development of their students in guiding, supervising and providing information that deals with events or problems. This is in accordance with Darmasih (2009) research, more and more adolescents get the provision of knowledge information about sex from other people the better the behaviour of adolescents in preventing premarital sex and vice versa ( $p=$ value 0.022$)$. Research Tinah and Sri (2010), also stated the same thing, the better the level of knowledge, the better his attitude towards things, the less knowledge he got, the more negative his attitude towards things. It can be concluded that adolescents who have a high level of knowledge about sexuality will tend to have a positive attitude towards premarital sex. Before teenagers who have a low level of knowledge about sex, they tend to be negative about marital sex.

Educators are required to be able to provide information and be able to be people who can provide support, attention, advice, and confidence so that their students can take care of themselves in order to avoid sexual behaviour that is not obvious. According to Soetjiningsih (2012), there needs to be a concern for people others or society forth a dap adolescent reproductive health with the understanding of safe sex and healthy, so it can improve the health of adolescent life and can be saved from the risk of unhealthy sexual behaviour if it is available to them. Thus it can be concluded that the more support a person gives to adolescents such as attention, supervision and the provision of appropriate information will certainly have an impact on the better attitude of a person in preventing premarital sex. According to Azwar (2012), information media as a means of communication has a major influence in the formation of one's opinions and beliefs, the existence of new information about something provides a new cognitive foundation for the formation of attitudes towards it.

\section{c. Role of Old People}

The results of the study of the role of parents in the prevention of premarital sex had the most influence of 72 respondents $(60.5 \%)$ and none of the 47 respondents (39.5\%). This means that respondents have good parenting, there is openness between parents and teenage children and there is information about sex from parents and other people who are considered important and most likely parents understand how important communication with their children in providing sexual impact information so that their children feel calmer and understand about it compared to teenagers who do not get attention from their parents, so that teens feel more comfortable talking to their peers / other people. This is in line with Putri's research (2011) which states that the higher the family's role in adolescents in preventing premarital sexual behaviour, the better and vice versa ( $p$-value $=0.000$ ).

Parents are the first and foremost environment for their children, therefore the position of parents in meeting needs, developing children's personality is very dominant. This is reinforced by Papa Lia et al (2008) that autonomous parents will be firm about the important values of norm rules and are willing to listen, explain and negotiate and can support the adolescent's self-confidence. While the results of the study that had no effect were 47 respondents (39.5\%). This might be due to other factors not examined, such as personal experience, religious institutions, culture, emotional factors, age, mass media, peers, knowledge (Azwar, 2012).

\section{d. The relationship of the role of educators to adolescent attitudes}

The results of the calculation of the statistical test analysis that has been done show that the role of educators on changes in adolescent attitudes in preventing premarital sex has a significant relationship with a significant level of $p=0.024, p<0.05$ ). From the results of the analysis obtained $O R=0.57$ means that the role of the existing educator supports efforts to prevent premarital sex has 6 times the opportunity to change attitudes in adolescents compared to the role of educators who do not have support. This means that there is a change of attitude in adolescents in the prevention of premarital sex because of the role of good educators to have benefits and are urgently needed so that the problem of premarital sex will not occur in schools. This is in accordance with Widyastuti's research (2014), that other people's attitudes have a greater influence on changes in adolescent attitudes in preventing premarital sex $(p=0,000)$. 


\section{e. Relationship between parents' role in adolescent attitudes}

The results of the analysis of the Chi-square statistical test conducted showed that there was no significant relationship between the role of parents and adolescent attitudes with $p$-value $=0.061$. The results of this data analysis came from cross-section study with $\mathrm{OR}=0.22$, meaning that the role of parents who support adolescent attitudes in preventing premarital sex has a chance of 0.22 times more positive attitude compared to the role of parents who do not support. This means that in the prevention of premarital sex carried out by adolescents get positive support from parents but far more positive support can be gained from the role of educators because the many extracurricular activities that exist in schools, the existence of supervision, guidance and positive direction can change adolescent attitudes. This study contradicts the research of Darmasih (2009) and Putri (2011) which states that the higher the role of families in adolescents, the better premarital sex behaviour of teenagers and vice versa ( $p$-value $=0,000$ ). Although the role of parents is not meaningful to adolescents' attitudes, this should concern all parties, where age factor of respondents who are in the range of early adolescents and the period of seeking self-identity so that they are easily influenced by the environment. According to Sarwono, (2012) in early adolescence, it began with rapid physical growth including in the sexual field. The occurrence of unbalanced development between body and spirit, between the mental functions of children, is awkward, rigid and full of conflict between the desires of freedom and feel depending on the role of parents, difficult to understand and understand adults. So that if this is not immediately resolved then behaviour arises. unhealthy and irresponsible teenagers.

This is in accordance with the opinion expressed by Kusmiran (2011) who said that in adolescence was a period of adolescent consolidation towards an adult period which was marked by a wall separating himself and the general public and egocentrism, so that the opinions of others and parents about sex were not has a large influence on the attitude taken by respondents. Overall the role of parents and educators all have a contribution to adolescent attitudes in the prevention of premarital sex, this is probably because teenagers have a lot to understand about the importance of maintaining reproductive health for health.

\section{f. Test results of regression analysis in prevention of premarital sex in adolescents}

The results of multivariate analysis to see the variables that have the greatest influence on the dependent variable, seen from exp (B) for significant variables, the greater the exp value (B) means the greater the effect on the dependent variable. In this data, the biggest influence on adolescent attitudes is the role of parents with $\mathrm{OR}=0.74 \%$ and the role of educators $\mathrm{OR}=0.57 \%$. This means that the role of parents is important for adolescents are able to give a religious response, attention, and fulfil their needs morally and materially so as to avoid the irregularities of marriage. Putri's research (2011), the higher the role of the family in adolescents, the premarital sexual behaviour the better and vice versa ( $p$-value $=0,000$ ). Involving the role of educators, parents carry out their duties well, adolescents tend to be less likely to be involved in problems with premarital sex (Sarwono, 2012).

\section{Conclusions}

Based on the results of the research on the distribution of respondents based on characteristics, the majority of respondents were in the early teen's range (14-16 years), the majority were female, and the majority of educators and parents supported. Based on bivariate analysis it can be concluded that there is a relationship between the role of educators there is no significant relationship to adolescent attitudes. Although the role of parents is not related, this is still a concern of all parties, because adolescents are a time to seek self-identity so that they are easily influenced by the environment.

Conflicts of Interest: there is no conflict of the greatest

\section{References}

Azwar, S. (2012). Sikap Manusia Teori dan Pengukurannya, Ed. Ke 2, Pustaka Pelajar, Yogyakarta. BKKBN. (2009). Laporan Mini Survei. Jakarta

Darmasih, R. (2009). Faktor Yang Mempengaruhi Perilaku Seks Pranikah Pada Remaja SMA Di Surakarta. Skripsi thesis, Universitas Muhammadiyah Surakarta. 
Dharma, K K. (2011). Metode Penelitian Keperawatan: Panduan Melaksanakan dan Menerapkan Hasil Penelitian. Jakarta. Trans InfoMedia

Kartono, K. (2013) Patologi Sosial 2 : Kenakalan Remaja, Ed.8, Rajagrafindo Persada, Jakarta.

Kusmiran. (2011). Kesehatan Reproduksi Remaja dan Wanita. Jakarta: Salemba Medika

Nursalam. (2008). Konsep Dan Penerapan Metodologi Penelitian Ilmu Keperawatan. Edisi 2. Jakarta: Salemba Medika.

Papalia, et. al. (2008). Human Development (Psikologi Perkembangan). Jakarta: Kencana.

Prihatin, T.W. (2007). Analisis Faktor - Faktor Yang Berhubungan Dengan Sikap Siswa SMA Terhadap Hubungan Seksual (Intercourse) Pranikah Di Kota Sukoharjo Tahun 2007. Thesis Universitas Diponegoro.

Purwanto, E, Kalsum, U. (2016). Gambaran Perilaku Seksual Pranikah Remaja Di Kota Samarinda Tahun 2016. Mahakam Nursing Journal Vol 2 No 3 Mei 2018 Hal 126-133.

Putri, A F, Risma, D, Zahtamal. (2011). Faktor-Faktor Yang Mempengaruhi Seks Pranikah Pada Remaja SMA Di Rengat Kabupaten Indragiri Hulu. Skripsi. Universitas Riau.

Sarwono, S W. (2012). Psikologi Remaja. Jakarta: PT. Raja Grafindo Persada.

Siswandwika, H D. (2017), Hubungan Peran Orang Tua Menurut Persepsi Siswa Dengan Sikap Remaja Tentang Seks Bebas Pada Siswa Kelas X SMA. $2^{\text {nd }}$ Seminar Nasional IPTEK Terapan (SENIT). 214218.

Soetjiningsih, (2012) Tumbuh Kembang Remaja dan Permasalahannya, ed. Ke 1, Sagung Seto, Jakarta.

Tinah \& Sri R.D.H, (2010) Hubungan Pengetahuan Dan Sikap Remaja Tentang Reproduksi Dengan Perilaku Seks Pranikah. Jurnal Kebidanan II(2)

Widyastuti,Y. Rahmawati, A \& Purnamaningrum, Y.E. (2014). Kesehatan Reproduksi, Fitramaya, Yogyakarta.

Yanti, F, Janah, N, Nurbaity. (2016). Dinamika Kecenderungan Gaya Hidup Hedonis Dan Perilaku Seks Bebas Pada Remaja Putri. Jurnal Ilmiah Mahasiswa Bimbingan dan Konseling FKIP Unsyiah 1(1) $40-47$.

Yusuf, S. (2013) Psikologi Perkembangan Anak dan Remaja, Ed. Ke 9, Remaja Rosdakarya, Bandung. 